\title{
Establishment of two nonnative parthenogenetic reptiles on Saba, Dutch Caribbean: Gymnophthalmus underwoodi and Indotyphlops braminus
}

\author{
Matthijs P. van den Burg ${ }^{1,2, *}$, Alwin Hylkema ${ }^{3,4}$, and Adolphe O. Debrot ${ }^{1,4}$
}

\author{
'Wageningen Marine Research, Wageningen University and Research, P.O. Box 57, 1780 AB Den Helder, the Netherlands. \\ ${ }^{2}$ BioCoRe S. Coop Calle Villagarcía 6, 28010, Madrid, Spain. \\ ${ }^{3}$ Coastal and Marine Systems, University of Applied Sciences Van Hall Larenstein, P.O. Box 1528, 8901 BV Leeuwarden, the Netherlands. \\ ${ }^{4}$ Marine Animal Ecology group, Wageningen University and Research, P.O. Box 338, 6700 AH Wageningen, the Netherlands. \\ "Corresponding author (thijs.burg@gmail.com)
}

Edited by: Robert Powell. Date of publication: 21 September 2021

Citation: van den Burg MP, Hylkema A, Debrot AO (2021) Establishment of two nonnative parthenogenetic reptiles on Saba, Dutch Caribbean: Gymnophthalmus underwoodi and Indotyphlops braminus. Caribbean Herpetology, 79, 1-5.

DOI: https://doi.org/10.31611/ch.79

The native herpetofauna of the Lesser Antillean island of Saba $\left(13 \mathrm{~km} 2 ; 17.63^{\circ} \mathrm{N},-63.24^{\circ} \mathrm{W}\right)$ includes one snake, Alsophis rufiventris, and four species of lizards, Anolis sabanus, Iguana melanoderma, Sphaerodactylus sabanus, and Thecadatylus rapicauda (Powell et al. 2015). Here, we report the establishment of both Gymnophthalmus underwoodi Grant, 1958 and Indotyphlops braminus (Daudin, 1803) on the island.

We have observed and recorded smooth-scaled tegulets (Gymnophthalmus underwoodi) since May 2020 at numerous locations across Saba (Fig. 1). We captured five individuals with snout-vent lengths of 23.12-40.64 $\mathrm{mm}$ and preserved a single specimen $(\mathrm{SVL}=40.64 \mathrm{~mm}$ ) that will be cataloged in the collection of the Naturalis Biodiversity Center in Leiden, The Netherlands (Fig. 2). We encountered G. underwoodi in a wide range of habitats, including gardens, dry forest, manchineel (Hippomane mancinella) forests, and grass-overgrown rocky slopes. Subcaudal scale (smooth) and head scalation morphology of the five captured individuals conformed to diagnostic characters of G. underwoodi (Cole et al. 1990, Williamson \& Powell 2004, Recoder et al. 2018). We used non-native records from iNaturalist (van den Burg et al. 2020), as well as observations reported by on-island researchers to further infer the distribution of G. underwoodi (Fig. 1). Overall, G. underwoodi appears to be present across at least $>50 \%$ of the island's surface, with the highest observed elevation at $711 \mathrm{~m}$. Although the earliest verifiable observation dates from May 2020, given that G. underwoodi is known for rapid population growth (Daltry 2007), the island-wide distribution suggests an earlier arrival.

Gymnophthalmus underwoodi has a wide native distribution, occurring both on the South American continent and throughout the Lesser Antilles (Recoder et al. 2018); however, island populations in the northern Lesser Antilles are currently believed to have been introduced (Daltry 2007, Powell et al. 2011). This report adds Saba to the list of Lesser Antillean island on which the species has been recorded: Antigua, Barbados, Barbuda, Dominica, Grenada, Guadeloupe (Basse-Terre, Grande-Terre, La Desirade, Les Saintes, Marie-Galante), Martinique, Montserrat, Nevis, St. Barthélemy, St. Kitts, St. Martin, and St. Vincent and the Grenadines (Snyder et al. 2017). On Saba, direct competition with native herpetofauna is considered unlikely. Although Sphaerodactylus sabanus and G. underwoodi both occupy habitat with abundant leaflitter, highest-activity periods are non-overlapping, with that of $G$. underwoodi coinciding with the heat of the day and that of $S$. sabanus occurring from late afternoon to midnight (Powell et al. 2015).

A local resident observed the first Brahminy Blindsnake (Indotyphlops braminus) on Saba when she encountered several individuals in her garden in Windwardside from May to July 2021 (Fig. 1). These observations involved at least two different individuals based on size differences; one with a total length of $\sim 6 \mathrm{~cm}$ (see https:// www.inaturalist.org/observations/54618365), the other $>10 \mathrm{~cm}$ (Fig. 3); neither was collected. Head scalation patterns are similar to those described in Hedges et al. (2014) and coloration and head shape were typical of the 


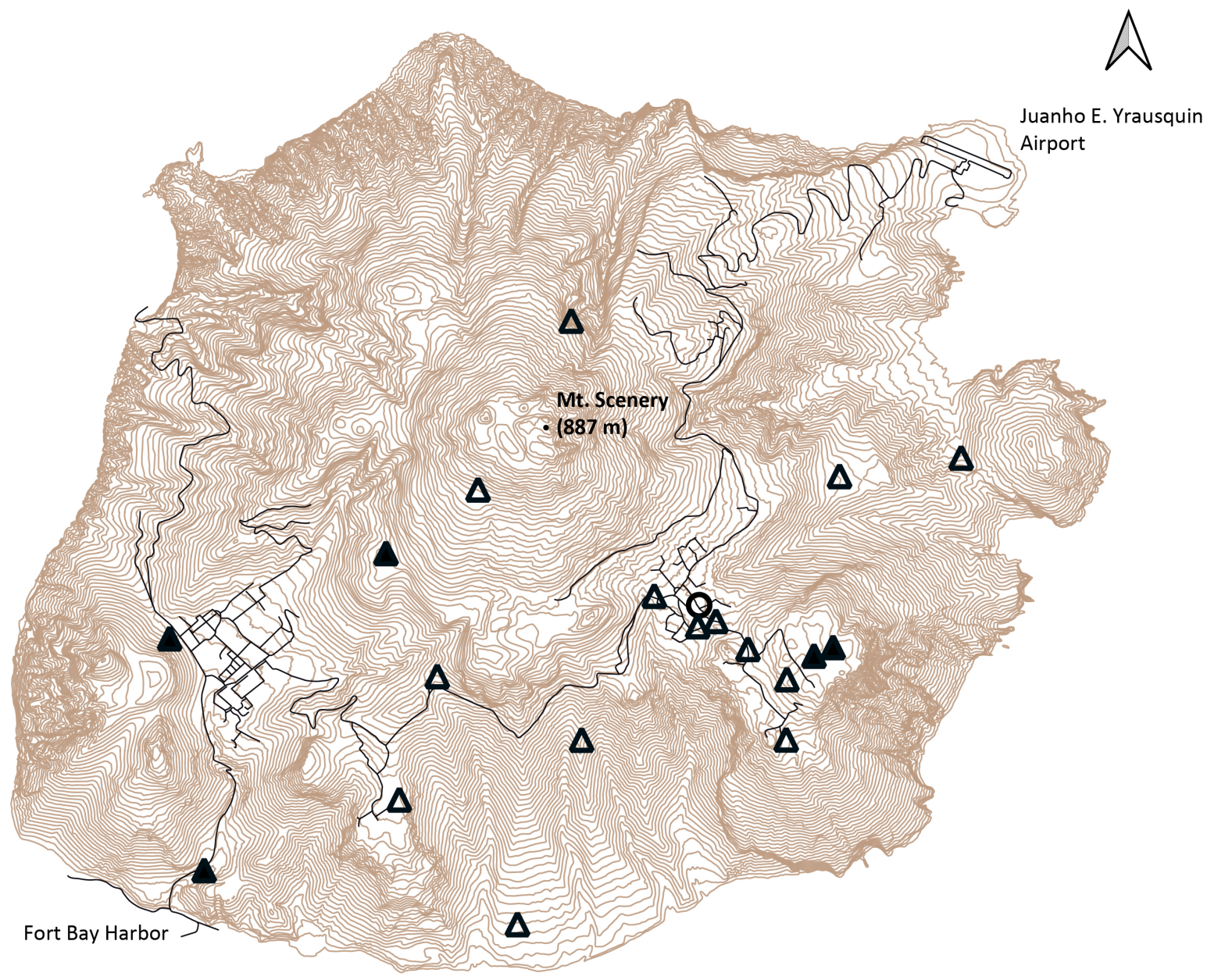

\section{Species}

$\Delta$ Gymnophthalmus underwoodi O Indotyphlops braminus

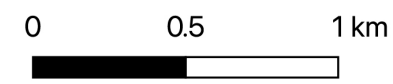

Figure 1. Contour map of Saba, Dutch Caribbean, with localities where Gymnophthalmus underwoodi (triangles) and Indotyphlops braminus (circle) have been captured (filled) or observed (open). Contour lines at 10-meter intervals.

species (S. B. Hedges, pers. comm.). No other observations from Saba are presently known. Although I. braminus is believed to have recently arrived in the Caribbean region (Censky \& Hodge 1997), its occurrence on Saba is not surprising given that this widely introduced species (Rato et al. 2015) is already known from a large number of Lesser Antillean islands: Anguilla, Barbados, Guadeloupe, La Désirade, Martinique, Montserrat, Petite St. Vincent, St. Barthélemy, St. Eustatius, St. Kitts, and St. Martin (Henderson \& Breuil 2012, Lorvelec et al. 2016, Snyder et al. 2019).

Although currently no native scolecophidians have been documented for Saba (Powell et al. 2015), targeted fieldwork should be implemented now that Indotyphlops braminus has been recorded. If a native species is present, resource competition could occur given the similar feeding habits of blindsnakes (Webb et al. 2001). Additionally, I. braminus is believed to have greater reproductive potential than native Lesser Antillean scolecophidians (Snyder et al. 2019), which if present could threaten a local population of a native species. That native species can go unnoticed was confirmed by the recent discovery of Antillotyphlops geomotus on neighboring St. Eustatius (van Wagensveld et al. 2020). 


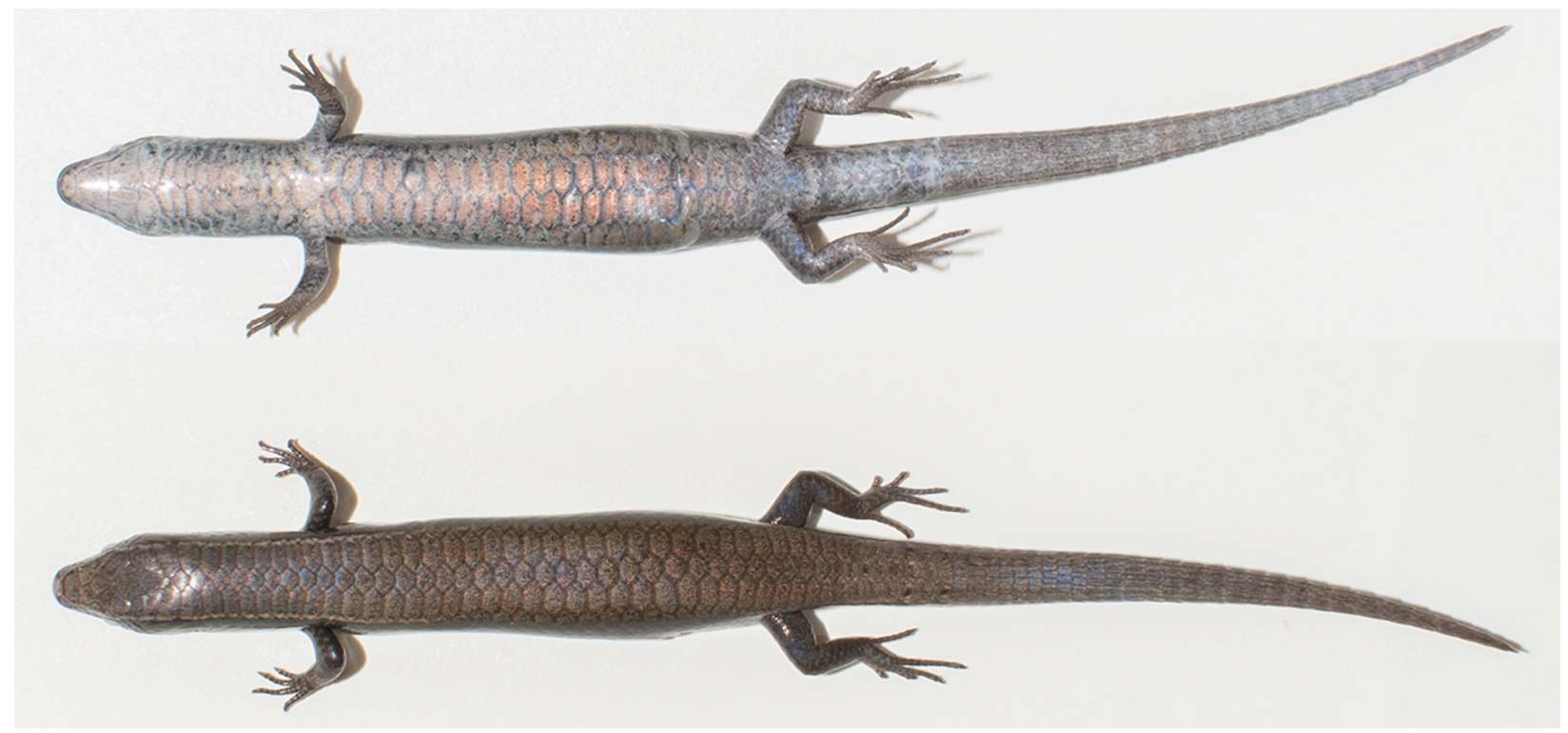

Figure 2. Gymnophthalmus underwoodi specimen $(\mathrm{SVL}=40.64 \mathrm{~mm})$ collected on Saba, Dutch Caribbean. Photos by M.P. van den Burg.

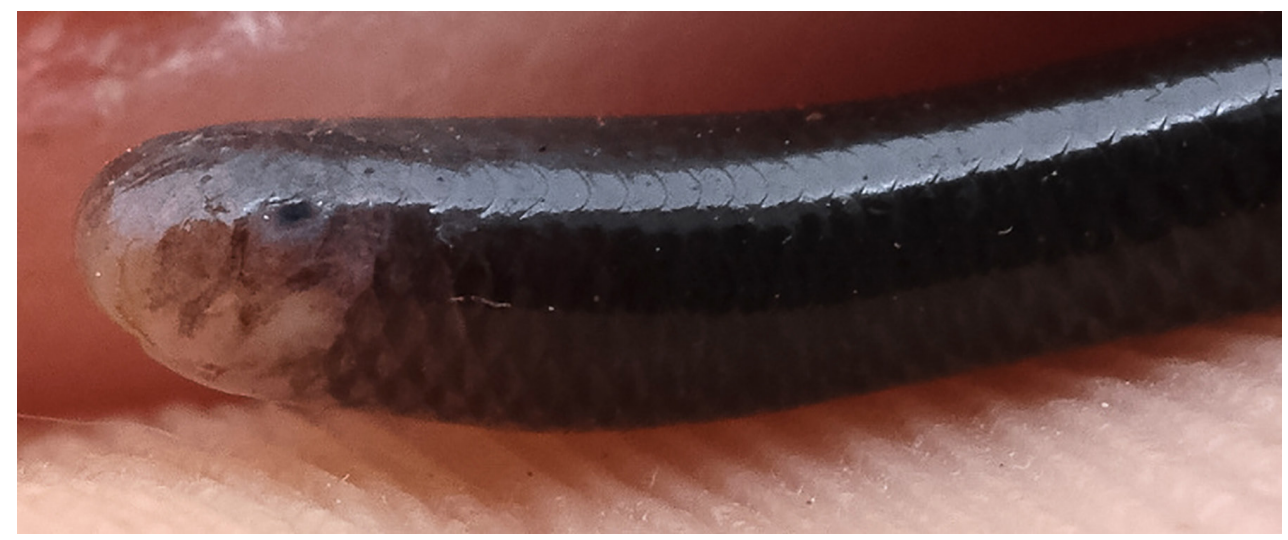

Figure 3. Lateral view of the head of an Indotyphlops braminus observed on Saba, Dutch Caribbean. Photo by Debbie Verdult.

Both Indotyphlops braminus and Gymnophthalmus underwoodi are established on several other Lesser Antillean islands as well as in Florida (USA). Given that most Saban inter-island traffic of goods and people occurs with neighboring St. Martin, populations there are the most likely source of the Saban introductions. On neighboring St. Eustatius, also part of the Dutch Caribbean but with less frequent traffic connections with St. Martin, only I. braminus is present, although its presence has been inconsistently reported (Powell 2006, 2011, Henderson \& Breuil 2012, Powell et al. 2015, van Wagensveld et al. 2020).

Overall, our report doubles the number of established nonnative amphibians and reptiles on Saba, adding Indotyphlops braminus and Gymnophthalmus underwoodi to Eleutherodactylus johnstonei and Hemidactylus mabouia. Nonnative species now comprise $40 \%$ of the total terrestrial herpetofauna.

Invasive alien species (IAS) are among the top drivers of worldwide biodiversity loss (Kaiser 1999, Butchart et al. 2010) and ecosystem change (IPBES 2019). The high threat that IAS pose within the Dutch Caribbean has been previously documented (Debrot et al. 2011, van der Burg et al. 2012, van Buurt and Debrot, 2011, 2012) and key elements toward implementation of a joint IAS strategy have been drafted (Smith et al. 2014). Since then, however, the need to address IAS has been highlighted as a major policy issue within two successive ministerial nature and environment policy plans (EZ 2013, LNV, I\&W and BZK 2020) but has not yet been implemented. Our results serve to illustrate the continuing problem of preventing and controlling the spread of nonnative species and potential IAS, and emphasize the need for swift and decisive action to address this escalating threat to the unique and 
vulnerable endemic biodiversity of the windward Dutch Caribbean (Bos et al. 2018).

\section{Acknowledgements}

Fieldwork was financed by the Ministry of Agriculture Nature and Food Quality (LNV) as part of their "BO" policy support research program with Wageningen University and Research under the project BO-43-117-006 and project number 4318100346-1. We would like to thank both Peter Johnson and Debbie Verdult for sharing their sightings.

\section{References}

Bos OG, Bakker PAJ, Henkens RJHG, de Freitas JA, Debrot AO (2018) Preliminary checklist of extant endemic species and subspecies of the windward Dutch Caribbean (St. Martin, St. Eustatius, Saba and the Saba Bank). Wageningen University \& Research Report C067/18, 69 pp.

Butchart SH., Walpole M, Collen B, van Strien A, Scharlemann JPW, Almond REA, Baillie JEM, Bomhard B, Brown C, Bruno J, Carpenter KE, Carr GM, Chanson J, Chenery AM, Csirke J, Davidson NC, Dentener F, Foster M, Galli A, Galloway JN, Genovesi P, Gregory RD, Hockings M, Kapos V, Lamarque JF, Leverington F, Loh J, McGeoch MA, McRae L, Minasyan A, Morcillo MH, Oldfield TEE, Pauly D, Quader S, Revenga C, Sauer JR, Skolink B, Spear D, Stanwellsmith D, Stuart SN, Symes A, Tierney M, Tyrrell TD, Vie JC, Watson R (2010) Global biodiversity: indicators of recent declines. Science, 328, 1164-1168. Article

Censky EJ, Hodge K (1997) Geographic distribution: Ramphotyphlops braminus. Herpetological Review, 28, 210.

Cole CJ, Dessauer HC, Townsend CR, Arnold MG (1990) Unisexual lizards of the genus Gymnophthalmus (Reptilia: Teiidae) in the Neotropics: Genetics, origin and systematics. American Museum Novitates, 2994, 1-29.

Daltry JC (2007) An introduction to the herpetofauna of Antigua, Barbuda and Redonda with some conservation recommendations. Applied Herpetology, 4, 97-130. Article

Debrot AO, van Buurt G, Vermeij MJA (2011) Preliminary overview of exotic and invasive marine species in the Dutch Caribbean. IMARES Report C188/11. 29 pp.

EZ (Dutch Ministry of Economic Affairs) (2013) Natuurbeleidsplan Caribisch Nederland 2013-2017. The Hague, the Netherlands, $55 \mathrm{pp}$.

Hedges SB, Marion AB, Lipp KM, Marin J, Vidal N (2014) A taxonomic framework for typhlopid snakes from the Caribbean and other regions (Reptilia, Squamata). Caribbean Herpetology, 49, 1-61. Article

Henderson RW, Breuil M (2012) Lesser Antilles, pages 148-159. In: Powell R, Henderson RW, editors, Island lists of West Indian amphibians and reptiles. Bulletin of the Florida Museum of Natural History, 51, 85-166.

IPBES (2019) Global Assessment Report on Biodiversity and Ecosystem Services of the Intergovernmental Science-Policy Platform on Biodiversity and Ecosystem Services. Brondizio ES, Settele J, Díaz S, NGO HT, editors (IPBES Secretariat, Bonn, Germany). Article

Kaiser J (1999) Stemming the tide of invading species. Science, 285, 1836-1841. Article

Lorvelec O, Berchel J, Barré N (2016) First report of the Flowerpot Blindsnake, Indotyphlops braminus (Daudin, 1803), from La Désirade (Guadeloupe Archipelago, the French West Indies). Caribbean Herpetology, 55, 1-2. Article

LNV, I\&W and BZK (2020) Plan voor land en water: beleidsplan natuur en milieu Caribisch Nederland 2020-2030, $52 \mathrm{pp}$.

Powell R (2006) Conservation of the herpetofauna on the Dutch Windward Islands: St. Eustatius, Saba, and St. Maarten. Applied Herpetology, 3, 293-306. Article

Powell R (2011) Conservation of the herpetofauna on the Dutch Windward Islands: St. Eustatius, Saba, and St. Maarten, pages 189-204. In: Hailey A, Wilson BS, Horrocks JA, editors, Conservation of Caribbean Island Herpetofaunas, Volume 2: Regional Accounts of the West Indies (Brill, Leiden, The Netherlands). Article 
Powell R, Henderson RW, Farmer MC, Breuil M, Echternacht AC, van Buurt G, Romagosa CM, Perry G (2011) Introduced amphibians and reptiles in the greater Caribbean: patterns and conservation implications, pages 63-143. In: Hailey A, Wilson BS, Horroks JA, editors, Conservation of Caribbean Island Herpetofaunas, Volume 1, Conservation Biology and the Wider Caribbean (Brill, Leiden, The Netherlands). Article

Powell R, Henderson RW, Parmerlee JS Jr. (2015) The Reptiles and Amphibians of the Dutch Caribbean: Saba, St. Eustatius, and St. Maarten. 2nd ed., revised and expanded. Nature Guide Series No. 004 (Dutch Caribbean Nature Alliance, Kralendijk, Bonaire).

Rato C, Silva-Rocha I, González-Miras E, Rodríguez-Luque F, Fariña B, Carretero MA (2015) A molecular assessment of European populations of Indotyphlops braminus (Daudin, 1803). Herpetozoa, 27, 179-182.

Recoder RS, Dal Vechio F, Marques-Souza S, Teixeira Jr. M, Silva-Da-Silva M, Santos-Jr AP, Ribeiro S, Barrio-Amorós C, Rodrigues MT (2018) Geographic variation and taxonomy of red-tailed Gymnophthalmus (Squamata: Gymnophthalmidae) from Amazonian savannas. Zootaxa, 4497, 61-81. Article

Smith SR, van der Burg WJ, Debrot AO, van Buurt G, de Freitas JA (2014) Key Elements Towards a Joint Invasive Alien Species Strategy for the Dutch Caribbean. IMARES Report C020/14, 104 pp.

Snyder SJ, Schmidt RE, McMullin ER, Parker BF, Ferus HL (2017) Gymnophthalmus underwoodi Grant, 1958 (Reptilia: Gymnophthalmidae), a new record for the island of Montserrat. Check List, 13, 2153. Article

Snyder SJ, Schmidt RE, Tirard N (2019) First report of the Brahminy Blindsnake, Indotyphlops braminus (Daudin), from the Caribbean island of Montserrat. Caribbean Herpetology, 65, 1-2. Article

Van der Burg WJ, de Freitas J, Debrot AO, Lotz LAP (2012) Naturalised and invasive alien plant species in the Caribbean Netherlands: status, distribution, threats, priorities and recommendations. PRI report 437. IMARES Report C185/11, 82 pp.

Van Buurt G, Debrot AO (2011) Introduced agricultural pests, plant and animals diseases and vectors in the Dutch Caribbean, with an "Alert species" list. IMARES Report number C193/11, 35 pp.

Van Buurt G, Debrot AO (2012) Exotic and invasive terrestrial and freshwater animal species in the Dutch Caribbean. IMARES Report number C001/12, 37 pp.

van den Burg MP, Van Belleghem SM, De Jesús Villanueva CN (2020b) The continuing march of common green iguanas: arrival on mainland Asia. Journal for Nature Conservation, 57, 125888. Article

van Wagensveld T, van Staa S, Butôt R (2020) Discovery of the Leeward Blindsnake, Antillotyphlops geotomus (Thomas, 1966), on St. Eustatius, Caribbean Netherlands. Caribbean Herpetology, 69, 1-3. Article 